\title{
PENGEMBANGAN MEDIA DAUR ULANG BERBASIS KECERDASAN JAMAK DALAM PENINGKATAN KETERAMPILAN HIDUP ANAK USIA DINI
}

\author{
Yuliani Nurani \\ FIP Universitas Negeri Jakarta (email: yuliani.nurani@yahoo.com)
}

\begin{abstract}
Pengembangan Media Daur Ulang Berbasis Kecerdasan Jamak dalam Peningkatan Keterampilan Hidup Anak Usia Dini. Penelitian ini bertujuan untuk menghasilkan suatu model pengembangan media daur ulang berbasis kecerdasan jamak bagi anak usia dini. Penelitian ini menggunakan desain penelitian dan pengembangan. Semua anak yang menjadi subjek penelitian adalah anak usia dini yang berusia 3-6 tahun yang belajar di Pos PAUD di DKI Jakarta. Anak usia dini yang menjadi sampel penelitian dipilih berdasarkan kriteria yang sesuai dengan kebutuhan model penelitian ini. Data yang dibutuhkan dikumpulkan melalui kuesioner, catatan lapangan dan asesmen perkembangan anak. Data Dianalisis secara kualitatif dan kuantitatif. Hasil penelitian menunjukkan bahwa pengembangan media daur ulang berbasis kecerdasan jamak dalam keterampilan hidup anak usia dini berhasil terbukti dengan meningkatnya keterampilan hidup anak usia dini yang belajar di Pos PAUD DKI Jakarta.
\end{abstract}

Kata Kunci: media daur uang, kecerdasan jamak, keterampilan hidup, anak usia dini, Pos PAUD

\begin{abstract}
Developing a multiple intelligences-based recycling media to improve the life skills for early childhood children. The purpose of this research is to create a model for the development of multiple intelligences-based recycling media for early childhood children. This study employs design and development research. The samples of this study are 3 to 6 years old children studying at Pos PAUD in Jakarta and selected based on certain criteria. Questionnaires, field notes and child development assessment are utilized to obtain necessary data. These data are analyzed both qualitatively and quantitatively. This study finds that multiple intelligences-based recycling media improved children' life skills.
\end{abstract}

Keywords : recycled media, multiple intelligences, life skills, early childhood, and Pos PAUD

\section{PENDAHULUAN}

Peningkatan keterampilan hidup bagi anak usia dini dibutuhkan agar anak dapat bertanggung jawab ter- hadap kebutuhan dasarnya sehari-hari seperti makan, minum, mandi sendiri, memakai baju, sandal, sepatu tanpa bantuan orang lain. Proses pembelajar- 
an pada anak usia dini hendaknya dilakukan dengan tujuan memberikan konsep dasar yang memiliki kebermaknaan bagi anak melalui pengalaman nyata yang memungkinkan anak untuk menunjukkan aktivitas dan rasa ingin tahu (curiousity) secara optimal. Kemudian menempatkan posisi guru sebagai pendamping, pembimbing, dan fasilitator bagi anak. Proses pendidikan seperti ini dapat menghindari bentuk pembelajaran yang hanya berorientasi pada kehendak guru dan menempatkan anak secara pasif dan guru menjadi dominan.

Pada kenyataannya, pembelajaran berpusat pada anak untuk selama ini masih jauh dari yang diharapkan. Proses pembelajaran di banyak lembaga pendidikan masih berpusat pada guru (teacher centered) dan belum berpusat pada anak (student centered), cenderung tidak mengembangkan cara berpikir kritis, kreatif dan inovatif. Fenomena yang tampak adalah banyak guru yang lebih menginginkan anaknya duduk manis, diam, dan menjadi pendengar saja. Anak kreatif yang selalu bergerak dan banyak bertanya justru dipandang sebagai anak yang nakal yang tidak disukai oleh guru dan selalu dianggap memusingkan.

Keterampilan hidup atau kecakapan hidup yang lebih popular dengan istilah life skills haruslah ditumbuhkembangkan sejak dini. Maddaleno dan Infante (2001:54), mengidentifikasi adanya tiga katagori life skills, yaitu keterampilan sosial dan interpesonal, keterampilan kognitif, dan keterampilan meniru emosi (emosional copying skills). Melalui berbagai keterampilan hidup yang dikuasainya, diharapkan anak akan mampu bertahan hidup dan bertanggung jawab terhadap diri mereka sendiri. Catron dan Allen (1999: 205) menyatakan bahwa pada dasarnya pembelajaran kecakapan hidup bertuju-an agar anak mampu mengurus diri sendiri (self help) dan untuk kemudian mampu menolong orang lain (social skill) sebagai suatu bentuk kepedulian dan tanggungjawab sosialnya sebagai salah satu anggota keluarga dan masyarakat.

Aspek keterampilan hidup untuk kemandirian sesuai dengan karakteristik perkembangan anak usia dini antara lain adalah dapat mempergunakan serbet dan membersihkan tumpahan makanan, dapat menuangkan air dan minum sendiri, dapat makan sendiri, dapat memakai dan melepas pakaian sendiri, dapat membuka kancing baju depan yang besar, dapat memakai sepatu tanpa tali, dapat mencuci tangan sendiri, dapat ke kamar kecil dan membersihkan dirinya saat buang air, membuka dan menutup keran air, menyikat gigi dengan diawasi, dan menyeka hidung saat diperlukan.

Salah satu faktor utama yang mendukung terjadinya proses belajar mandiri dalam diri anak adalah interaksi anak dengan lingkungan. Untuk itu, salah satu tugas guru anak usia dini adalah menciptakan lingkungan yang kondusif bagi tumbuhnya motivasi belajar dan segala kemampuan yang dimiliki anak. Salah satu faktor lingkungan yang penting dalam hal ini adalah media pendidikan. Merujuk pada pendapat Sadiman (2003:16-17) bahwa melalui penggunaan media 
pendidikan secara tepat dan bervariasi dapat mengatasi sifat pasif pada anak didik. Untuk itu, pengadaan dan pemanfaatan media perlu dilakukan agar proses belajar anak dapat terjadi secara optimal.

Pada dasarnya, setiap objek yang ada di lingkungan sekitar dapat dijadikan media pendidikan dan sumber belajar bagi anak, tidak terkecuali barang bekas atau yang seringkali disebut dengan istilah sampah yang dapat didaur ulang. Barang bekas atau sampah umumnya dapat ditemukan di lingkungan sekitar sehingga mudah didapat dan tidak membutuhkan biaya besar untuk mendapatkannya bahkan dapat diperoleh dengan cuma-cuma. Selain itu, saat ini terdapat berbagai jenis bahan, bentuk, warna, tekstur dan ukuran yang beraneka ragam, menjadikan sampah atau barang bekas ini mampu menumbuhkan keaktifan dan merangsang ide-ide baru pada guru ataupun anak dalam berkreasi.

Pada kenyataannya, di lembaga pendidikan anak usia dini kegiatan belajar anak lebih disibukkan oleh kegiatan baca, tulis, dan hitung, dan kegiatan lain seperti mewarnai, menggambar atau menyusun tumpukan balok-balok. Kegiatan lain untuk menolong diri sendiri seperti memakai sepatu dan kaos kaki, membuka tutup tempat makanannya ataupun membuat minuman untuk dirinya sendiri jarang dilakukan, sehingga keyakinan untuk membangun konsep diri bahwa "Yes, I can" tampak masih rendah. Hal ini terlihat dari sikap anak yang cepat putus asa atau selalu buru-buru meminta tolong pada gurunya dengan mengatakan "Bu... aku tidak bisa! atau bantu aku dong Bu ...", ketika diberi tugas untuk mengerjakan sesuatu.

\section{Kecerdasan Jamak}

Kecerdasan jamak adalah ungkapan dari cara berpikir seseorang yang dapat dijadikan modalitas dalam belajar melalui bermain. Berdasarkan hasil penelitiannya, Gardner (1999:8) menemukan bahwa: (1) setiap manusia memiliki delapan spektrum kecerdasan yang berbeda-beda dan menggunakannya dengan cara-cara yang sangat individual; (2) setiap orang dapat mengembangkan kesemua kecerdasan sampai mencapai suatu tingkat yang memadai; (3) setiap kecerdasan bekerjasama satu sama lain secara kompleks karena dalam tiap kecerdasan ada berbagai cara untuk menumbuhkan salah satu aspeknya. Bagi Gardner tidak ada anak yang bodoh atau pintar, yang ada adalah anak menonjol dalam salah satu atau beberapa jenis kecerdasan (http://www.family-discovery.com/detail2.asp?menu=detail2\&id=6).

Setiap individu memiliki cara yang berbeda untuk mengembangkan berbagai kecerdasan yang ada dalam dirinya. Untuk itulah, dalam proses pendidikan dan pembelajaran khususnya setiap anak harus mendapat perlakuan yang berbeda sesuai dengan potensi kecerdasannya masing-masing. Untuk hal ini dikenal adanya istilah "the right man on the right competences". Artinya, seorang anak akan dapat belajar bidang pengembangan apapun apabila anak diberi kesempatan untuk mempelajarinya sesuai dengan kecerdasan yang dimilikinya. Terdapat delapan aspek 
kecerdasan yang ada dalam diri manusia, yaitu: kecerdasan linguistik, logika matematika, kinestetik, visual spa- sial, musikal, intrapersonal, interpersonal, dan naturalistik (Amstrong, 2002:510).

\begin{tabular}{|c|c|c|}
\hline $\begin{array}{l}\text { Linguistik } \\
\text { - Berpikir lancar melalui } \\
\text { kata-kata } \\
\text { - Mengekspresikan ide yang } \\
\text { kompleks melalui kata- } \\
\text { kata } \\
\text { - Memahami arti dan urutan } \\
\text { kata }\end{array}$ & $\begin{array}{l}\text { Logika Matematika } \\
\text { - Menggunakan sistem angka } \\
\text { yang abstrak } \\
\text { - Menemukan hubungan } \\
\text { antara perilaku, obyek dan } \\
\text { ide-ide } \\
\text { - Menggunakan keterampilan } \\
\text { beralasan secara berurutan }\end{array}$ & $\begin{array}{l}\text { Kinestetik } \\
\text { - Berpikir melalui gerakan, } \\
\text { menggunakan tubuh } \\
\text { secara ekspresif } \\
\text { - Mengetahui kapan dan } \\
\text { bagaimana bereaksi } \\
\text { - Meningkatkan } \\
\text { keterampilan fisik }\end{array}$ \\
\hline $\begin{array}{l}\text { Visual Spasial } \\
\text { - } \text { Berpikir melalui } \\
\text { gambar } \\
\text { - Memvisualisasikan } \\
\text { Presentasi } 3 \text { aspek } \\
\text { - Menggunakan } \\
\text { imajinasi \& interpretasi } \\
\text { grafik secara kreatif }\end{array}$ & $\begin{array}{c}8 \\
\text { Kecerdasan } \\
\text { Jamak mencakup } \\
\text { berbagai kemampuan } \\
\text { Untuk: }\end{array}$ & $\begin{array}{l}\text { Musikal } \\
\text { - Berpikir melalui suara } \\
\text { dan irama } \\
\text { - Mereproduksi musik dan } \\
\text { notasi dalam lagu } \\
\text { - Sering memainkan } \\
\text { instrumen }\end{array}$ \\
\hline $\begin{array}{l}\text { Naturalistik } \\
\text { - Memahami dunia alamiah } \\
\text { - Membedakan, } \\
\text { mengklasifikasikan dan } \\
\text { menggunakan ciri-ciri, } \\
\text { fenomena, dll dari alam } \\
\text { - Berinteraksi dengan } \\
\text { mahluk hidup dan } \\
\text { tumbuhan }\end{array}$ & $\begin{array}{l}\text { Interpersonal } \\
\text { - Memahami suasana hati dan } \\
\text { perasaan orang lain } \\
\text { - Memiliki hubungan yang baik } \\
\text { dengan orang lain, menghibur } \\
\text { dalam berbagai perspektif } \\
\text { - Memegang peran dalam } \\
\text { kepemimpinan }\end{array}$ & $\begin{array}{l}\text { Intrapersonal } \\
\text { - Kesadaran diri kritis/ } \\
\text { tinggi } \\
\text { - Kesadaran akan } \\
\text { kekuatan dan kelemahan } \\
\text { diri individu } \\
\text { - Merefleksikan } \\
\text { kemampuan berpikir / } \\
\text { proses belajar }\end{array}$ \\
\hline
\end{tabular}

\section{Bagan 1 : Kecerdasan Jamak}

Sumber: Evangeline Harris Stefanakis. 2002. Multiple Intelligences and Portofolios: A Window Into The Learner's Mind . Portsmouth, NH: Heinemann.

\section{Media}

Sesuai dengan karakteristik pembelajaran dan kebutuhan belajar melalui media pada anak usia dini, maka peran media menjadi sangat penting. Istilah media berasal dari kata medium secara harfiah berarti perantara atau pengantar. Menurut Sadiman (2003:6), media adalah perantara atau pengantar pesan dari pengirim ke penerima pesan.
Dalam dunia pendidikan media adalah pengantar pesan pendidikan baik dari guru ke anak didik, dari anak didik ke guru ataupun dari anak didik ke anak didik yang lain. Penggunaan media dalam pembelajaran akan mempermudah anak usia dini untuk menerima berbagai pesan terutama untuk segala sesuatu yang belum diketahuinya. Media dapat dideskripsikan sebagai segala 
sesuatu yang dapat digunakan untuk menyalurkan pesan dari pengirim ke penerima sehingga dapat merangsang pikiran, perasaan, perhatian dan minat anak sedemikian rupa sehingga proses belajar terjadi.

Berdasarkan katagori dalam pemanfaatannya, media digolongkan ke dalam media jadi (media by utililization) dan media yang dirancang sesuai kebutuhan (media by design). Dalam penelitian ini yang dikembangkan adalah media yang dirancang sesuai kebutuhan dari mediabahan daur ulang. Berdasarkan pengertiannya, daur ulang adalah materi yang sama digunakan beberapa kali untuk membuat produk yang sama atau menyerupai sehingga dapat menghemat materi pokok yang diperlukan untuk produksi (Wirjoatmodjo dan Assegaf, 2004:42).

Daur ulang juga dapat diartikan sebagai proses memberi sentuhan baru pada barang lama atau bekas sehingga dapat digunakan kembali. Jadi, media daur ulang dapat diartikan sebagai barang-barang bekas di lingkungan sekitar yang dapat dimanfaatkan kembali sebagai bahan dasar dalam kegiatan seni dan kerajinan tangan. Barang bekas yang digunakan ini berfungsi sebagai perantara penyaluran informasi pengetahuan. Proses daur ulang terdiri atas kegiatan pemilahan, pengumpulan, pemrosesan, pendistribusian, pembuatan produk atau materi bekas pakai. Dalam proses daur ulang sebagai pembelajaran pada anak-anak dapat dimulai dengan pemilahan sampah yang dapat didaur ulang yaitu sampah padat yang tidak berbahaya bagi keselamatan atau kesehatan anak. Setelah itu, sam- pah tersebut dikumpulkan dan dikelompokkan. Kemudian semua sampah yang siap didaur ulang dibersihkan terlebih dahulu. Penggunaan alat-alat lain seperti lem, gunting, isolasi, stapler, dan pembolong kertas dapat membantu proses mendaur ulang sampah. Melalui kegiatan ini, anak akan belajar menghasilkan sebuah produk baru yang bermanfaat dari barang bekas atau sampah.

Dalam pendidikan anak usia dini, kegiatan penggunaan media daur ulang dapat dijadikan alternatif kegiatan pembelajaran. Penggunaan media daur ulang dalam pembelajaran sejak dini mampu menciptakan generasi mendatang yang lebih baik dalam hal pemeliharaan lingkungan; sehingga akan tercipta lingkungan hidup yang sehat bagi seluruh makhluk hidup. Selain itu, dengan pembiasaan dalam mendaur ulang sampah ditambah dengan kreativitas yang tinggi dalam memanipulasi media daur ulang, akan membantu anak dan masyarakat dalam peningkatan taraf hidupnya.

Berdasarkan hal tersebut dapat dikatakan bahwa kegiatan daur ulang sampah memiliki manfaat yang sangat baik, terutama dalam pengembangan keterampilan hidup yang nantinya mampu meningkatkan taraf hidup masyarakat. Kegiatan ini mampu mengembangkan berbagai kecerdasan anak karena bentuk, warna dan tekstur yang beragam dari kaleng, kertas, styrofoam dan plastik, memungkinkan media daur ulang ini mampu merangsang dan mengembangkan kreativitas serta daya imajinasi anak. Selain itu, penggunaan media daur ulang dalam kegiatan seni 
dan kerajinan tangan ini dapat merangsang keaktifan anak. Dalam hal ini, media daur ulang berguna untuk menimbulkan kegairahan belajar, memungkinkan interaksi langsung antara anak didik dengan lingkungan dan kenyataan, memungkinkan anak belajar secara mandiri menurut kemampuan dan minatnya.

Salah satu lembaga pendidikan nonformal yang memberikan layanan pendidikan pada anak usia dini adalah di Pos PAUD (Depdiknas, 2008: 9). Anak didik di Pos PAUD adalah anak usia 36 tahun yang tidak terlayani di lembaga PAUD lainnya, seperti di Taman Kanak-kanak dan Kelompok Bermain. Sebagai lembaga pendidikan nonformal, Pos PAUD belum mampu memberikan pelayanan yang optimal dalam meningkatkan k e t e r a m p i l a n hidup anak. Banyak faktor yang menyebabkan hal ini terjadi, salah satunya adalah kurang tersedianya media sebagai alat bantu utama dalam pembelajaran bagi anak usia dini. Permasalahan lainnya, karena kreativitas guru yang juga sangat terbatas dalam hal pengadaan, penggunaan dan pemanfaatan media pembelajaran. Kebanyakan guru selalu menggunakan media yang sudah jadi, yang didapat dengan cara membeli, sementara disisi lain anggaran di Pos PAUD sangat terbatas. Padahal media dapat juga dibuat dari bahan daur ulang seperti sampah atau barang bekas lainnya yang bertebaran di lingkungan sekitar, yang memiliki potensi tinggi untuk dijadikan media dalam pembelajaran kurang dimanfaatkan dan bahkan tetap dipandang sebagai sampah yang hanya untuk dibuang.

Tujuan penelitian ini adalah menghasilkan suatu model pengembangan media daur ulang berbasis kecerdasan jamak dalam meningkatkan keterampilan hidup anak usia dini. Secara empiris tujuan penelitian adalah memperoleh informasi tentang penerapan penggunaan media daur ulang berbasis kecerdasan jamak dalam meningkatkan keterampilan hidup anak usia dini pada Pos PAUD di DKI Jakarta.

\section{METODE}

Metode yang digunakan dalam penelitian ini adalah research and development (RED) dengan menggunakan analisis data gabungan, yaitu analisis data kualitatif dan kuantitatif. Langkah yang ditempuh dalam penelitian ini menggunakan pendekatan model $R \mathcal{E} D$ dari Borg dan Gall (2003:570) yang merekomendasikan sepuluh langkah, yaitu: (1) research and information collection; (2) planning; (3) develop preliminary form of product; (4) preliminary field testing; (5) main product revision, (6) main field testing, (7) operational product revision, (8) operational field testing, (9) final product revision, dan (10) dissemination and distribution. Selanjutnya, kesepuluh langkah tersebut dalam penelitian ini dimodifikasi menjadi 3 tahapan, yaitu: tahap pra pengembangan model dilaksanakan melalui studi pendahuluan meliputi pengumpulan informasi, mengkaji literatur, survei dan studi dokumentasi di Pos PAUD sampai dihasilkan data pendukung untuk pengembangan model awal; tahap pengembangan model dilakukan me- 
lalui prosedur pengembangan model media daur ulang berbasis kecerdasan jamak; dan tahap penerapan model dilakukan pada sekelompok anak usia dini berupa penggunaan media daur ulang berbasis kecerdasan jamak dalam rangka meningkatkan keterampilan hidup anak usia dini di Pos PAUD. Langkah selanjutnya, untuk melihat keefektifan pengembangan model dilakukan pengujian terbatas sebelum dan sesudah diterapkan model dengan metode eksperimen model single one shot case study, dan dihitung dengan Uji t.

Instrumen yang digunakan pada: tahap pra pengembangan berupa kuesioner yang berisi sejumlah daftar pertanyaan; pada tahap pengembangan model, seperangkat pedoman dan prosedur kerja berupa: (1) landasan konseptual pengembangan media; (2) prosedur kegiatan pengembangan; (3) pedoman catatan lapangan; (4) pelaksanaan kegiatan bermain; (5) asesmen perkembangan anak. Selanjutnya, pada $\boldsymbol{t a}$ hap penerapan model, dilakukan pada satu kelompok kecil yang terdiri dari 18 anak usia 5-6 tahun di Pos PAUD dengan instrumen berupa lembar catatan lapangan, lembar observasi, lembar klipping portofolio yang terangkum dalam lembar asesmen perkembangan anak. Aspek yang dinilai adalah 9 aspek kecerdasan jamak dan keterampilan hidup dalam rangka menolong diri. Instrumen pengukuran terdiri dari 9 butir dengan kriteria: belum berkembang (skor 1), berkembang (skor 2), berkembang sesuai harapan (skor 3) dan konsisten (skor 4). Penerapan hasil pengembangan dinyatakan berhasilapabila hasil asesmen perkembangan pada anak memenuhi kriteria berkembang sesuai harapan atau dengan skor minimal 27.

Hasil akhir yang dipentingkan dalam tahap ini adalah adanya perubahan yang membawa perbaikan (what works better) daripada kemengapaannya dan tidak untuk digeneralisasikan. Itu artinya, keterlaksanaan model (workable) yang telah dikembangkan dalam penelitian lebih mementingkan kemanfaatan model tersebut dalam praktek pendidikan bagi anak usia dini.

\section{HASIL}

\section{Hasil Pra Pengembangan}

Berdasarkan hasil studi pendahuluan tentang kondisi awal kompetensi guru ditemukan bahwa terdapat $86 \%$ guru yang belum memiliki kompetensi menggunakan media daur ulang berbasis kecerdasan jamak dalam meningkatkan keterampilan hidup anak usia dini pada pembelajaran di Pos PAUD, dengan alasan: (1) $81 \%$ belum tahu cara mengolah limbah yang didaur ulang, (2) $82 \%$ tidak tahu cara, prosedur dan tahapan membuat media daur ulang, dan (3) $87 \%$ adanya kecemasan bahwa media daur ulang berbahaya, tajam, kotor dan beracun. Dengan demikian, berarti pengembangan media daur ulang berbasis kecerdasan jamak perlu dikembangkan dalam rangka untuk meningkatkan keterampilan hidup anak usia dini di Pos PAUD. Untuk mengetahui kondisi awal anak sebelum diberikan perlakuan, terlebih dahulu diadakan assesmen. Berikut disajikan data kondisi awal anak dalam skala interval yang mencakup perhitungan rerata, median, modus, nilai maksimum, nilai 
minimum, standar deviasi dan varians sebagaimana ditunjukkan pada Tabel 1.

Tabel 1: Data Kondisi Awal Hasil Asesmen Perkembangan Anak

\begin{tabular}{ll}
\hline Keterangan & Skor \\
\hline Rerata & 150,78 \\
Median & 160 \\
Modus & 148 \\
Nilai Maksimum & 175 \\
Nilai Minimum & 130 \\
Standar Deviasi & 11,10 \\
Varians & 123,24 \\
Jumlah Skor Data Mentah & 2714 \\
Jumlah Responden & 18 \\
\hline
\end{tabular}

Selanjutnya, rangkuman deskripsi data kondisi awal tersebut disusun dalam tabel distribusi frekuensi yang ditunjukkan pada Tabel 2.

\section{Tabel 2: Distribusi Frekuensi}

\begin{tabular}{ccc}
\hline Interval & $\begin{array}{c}\text { Frekuensi } \\
\text { Absolut }\end{array}$ & $\begin{array}{c}\text { Frekuensi } \\
\text { Relatif }\end{array}$ \\
\hline $130-135$ & 1 & $5,6 \%$ \\
$136-141$ & 2 & $11,1 \%$ \\
$142-147$ & 3 & $16,7 \%$ \\
$148-153$ & 5 & $27,8 \%$ \\
$154-159$ & 3 & $16,7 \%$ \\
$160-165$ & 2 & $11,1 \%$ \\
$166-171$ & 1 & $5,6 \%$ \\
$172-177$ & 1 & $5,6 \%$ \\
& 18 & $100 \%$ \\
\hline
\end{tabular}

Jadi, data kondisi awal menunjukkan anak yang berada di bawah nilai rata-rata sebanyak 10 anak atau $55,6 \%$; sedangkan anak yang berada di atas kelas rata-rata sebanyak 8 anak atau $44,4 \%$.

\section{Hasil Pengembangan Model}

Sesuai dengan tujuan pengembangan, maka telah dihasilkan dua produk pengembangan, yaitu: (1) model konseptual media daur ulang berbasis kecerdasan jamak; dan (2) desain pembelajaran yang dapat meningkatkan keterampilan hidup anak usia dini. Dalam proses kerjanya kedua produk pengembangan ini bersifat hirarkikal dan saling berkesinambungan. Artinya, pada langkah awal dikembangkan media daur ulang berbasis kecerdasan jamak. Selanjutnya, pada langkah verikutnya dikembangkan desain pembelajaran yang dapat meningkatkan keterampilan hidup anak usia dini.

Pengembangan media daur ulang berbasis kecerdasan jamak bagi anak usia dini dikembangkan berdasarkan kajian teori, seperti tampak pada Bagan 2.

Media daur ulang merupakan bagian dari strategi pembelajaran yang dibuat sesuai dengan bahan belajar yang sudah disusun berdasarkan tujuan program berupa kompetensi dasar dan indikator berbasis kecerdasan jamak. Selain berdasarkan tujuan program, dalam pembuatan atau pengadaan media daur ulang diperlukan seleksi bahan yang sesuai dan tidak berbahaya bagi anak. Selanjutnya, dalam proses pembelajaran (learning process), media daur ulang berfungsi sebagai pengantar pesan atau sumber belajar yang dapat membantu tercapainya tujuan program. Kegiatan bermain yang dikembangkan berbasis kerja (learning by doing), kegiatan bermain yang berbasis stimulasi (learning by stimulation) dan kegiatan bermain yang berbasis contoh / teladan 
(learning by modelling). Seluruh kegiatan berrmain ini dikelola dalam kelas sentra (moving class activity). Sebagai pengukuran keberhasilan pembelajaran, dilakukan evaluasi pembelajaran (learning evaluation) berupa asesmen perkembangan anak melalui unjuk kerja be- rupa berbagai keterampilan hidup untuk menolong diri sendiri, seperti tata cara makan, minum, berpakaian, dan lainnya.

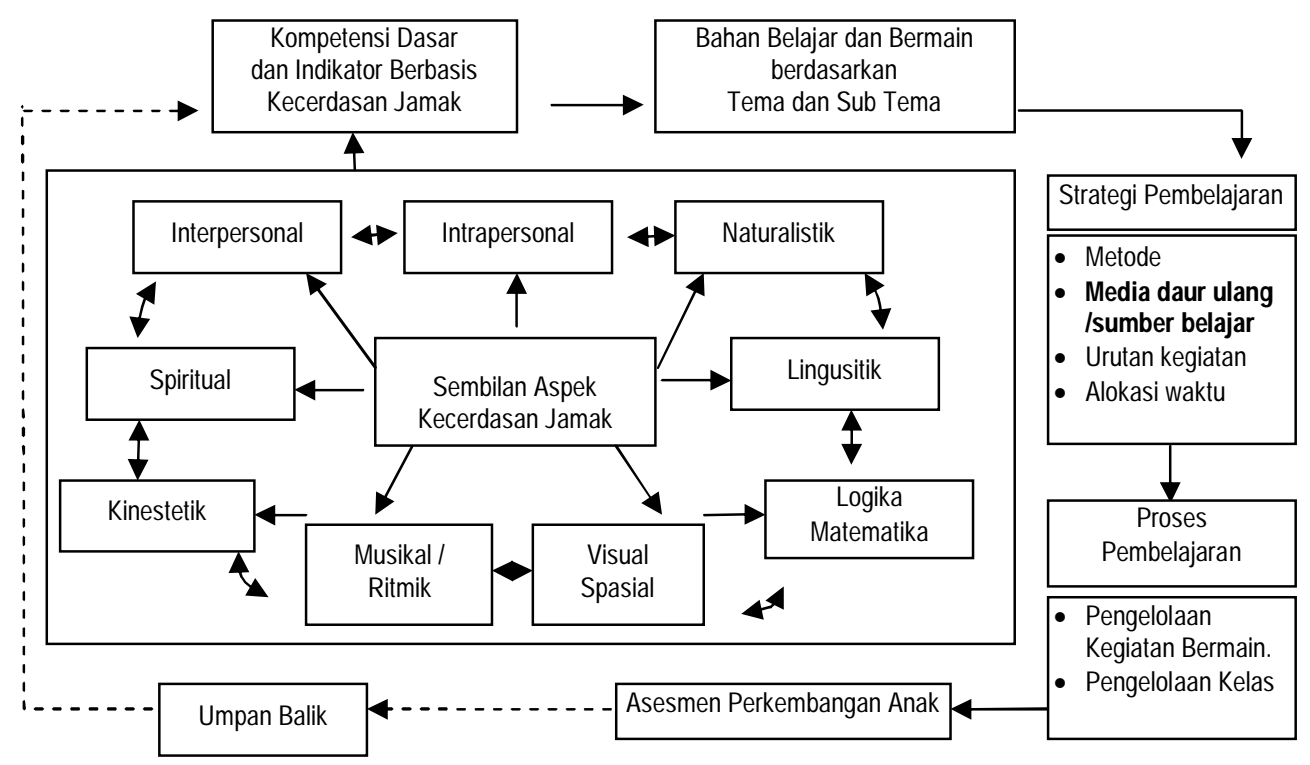

Bagan 2: Pengembangan Media Daur Ulang Berbasis Kecerdasan Jamak

Selanjutnya, dikembangkan desain pembelajaran dengan menggunakan media daur ulang berbasis kecerdasan bagi anak usia dini di Pos PAUD.

Produk media daur ulang yang dipilih dan digunakan dalam penelitian ini, antara lain adalah buku besar (big book), kantong pintar, gambar seri, media yang merupakan miniatur peralatan rumah tangga seperti meja makan, kulkas, peralatan makan, minum, mandi yang digunakan untuk membelajarkan keterampilan hidup bagi anak usia dini. Adapun spesifikasi media yang digunakan, sebagai berikut.
Pertama, media daur ulang yang digunakan adalah barang bekas di sekitar anak yang dapat dimanfaatkan kembali sebagai bahan dasar dalam kegiatan seni dan kerajinan tangan yang tidak berbahaya beracun, berbau, tidak tajam, dan aman bagi kesehatan anak.

Banyak media daur ulang yang terdapat di lingkungan sekitar anak. Oleh karena itu, peneliti membatasi media daur ulang yang digunakan adalah gelas dan botol plastik air mineral, botol minuman kaleng, styrofoam, kertas, karton serta kardus. 


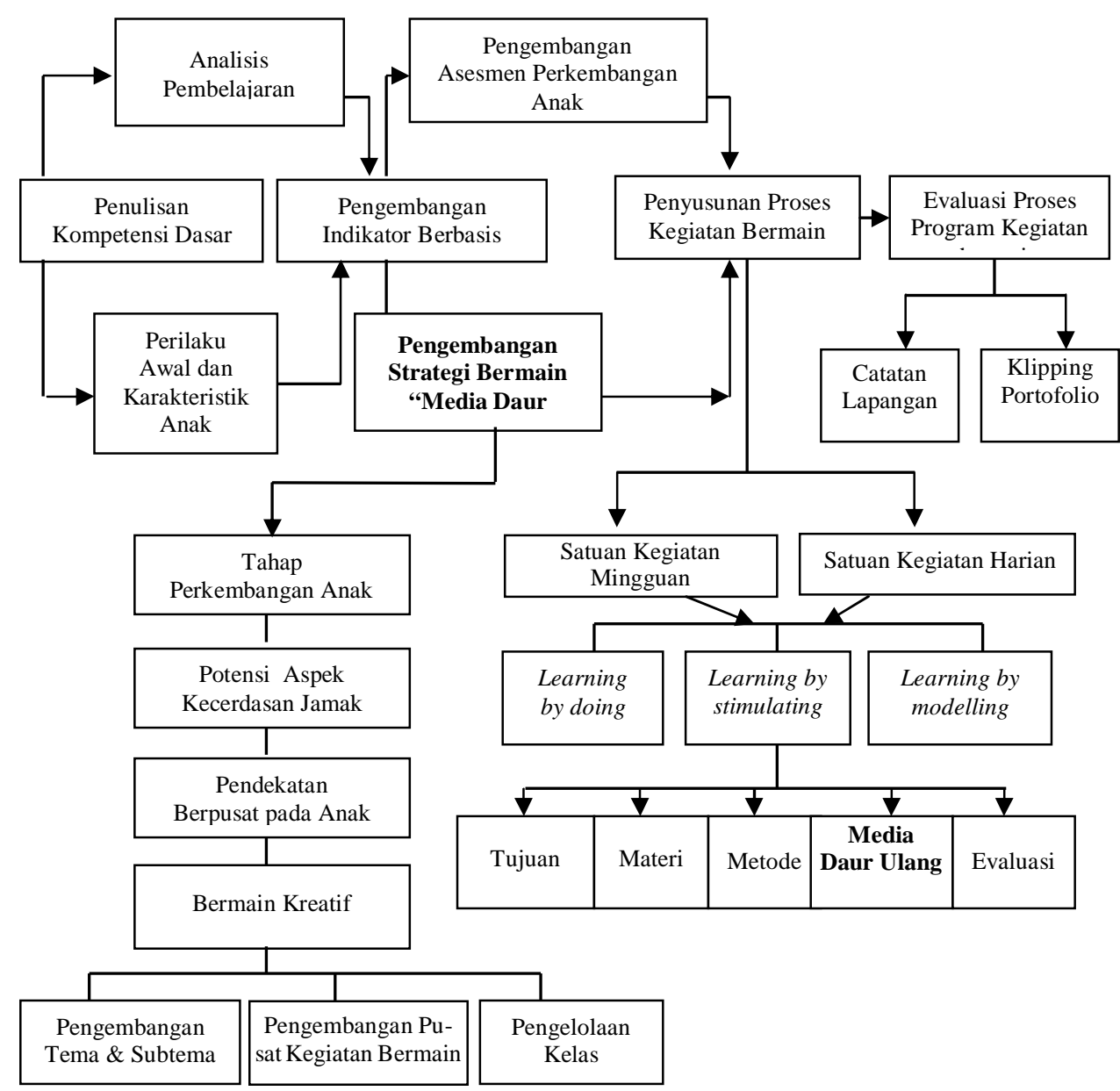

\section{Bagan 3 : Desain Pembelajaran dengan Media Daur Ulang Berbasis Kecerdasan Jamak}

Kedua, media daur ulang harus sesuai dengan tema pembelajaran, yaitu tema tentang rumah dengan sub tema ruang makan, ruang belajar, ruang keluarga, ruang dapur dan ruang tamu. Mediayang dibuat adalah berbagai peralatan yang terdapat di berbagai ruang tersebut.

Ketiga, media daur ulang yang dikembangkan sesuai dengan indikator keterampilan hidup yang akan dibe- lajarkan pada anak, seperti penggunaan peralatan makan dan minum, peralatan mandi, cara memakai baju, celana dan sepatu.

Keempat, dalam penelitian ini, anak diberikan fasilitas untuk mengembangkan kecerdasan jamak, utamanya pada aspek kecerdasan visual spasial dengan melakukan kegiatan mendaur ulang sampah menjadi sebuah hasil produk. Kelima, media daur ulang harus dapat 
memfasilitasi kegiatan belajar dengan melakukan (learning by doing), melalui stimulasi (learning by stimulation), dan belajar melalui pemodelan (learning by modelling). Selanjutnya, dikembangkan strategi pembelajaran keterampilan hidup dengan menggunakan media daur ulang yang sesuai dengan tahap perkembangan anak, potensi kecerdasan jamak, pendekatan berpusat pada anak, bermain kreatif berupa kreasi terhadap objek yang dibuat.

\section{Hasil Penerapan Model}

Penerapan dilakukan pada satu kelompok anak berusia 5-6 tahun di Pos PAUD yang berjumlah 18 anak. Hasil temuan lapangan diperoleh dari data hasil asesmen perkembangan anak di Pos PAUD selama 4 minggu dengan 12 kali pertemuan tatap muka. Data hasil penilaian dalam skala interval yang mencakup perhitungan rerata, median, modus, nilai maksimum, nilai minimum, standar deviasi dan varians dapat dilihat pada Tabel 3.

\section{Tabel 3: Data Hasil Asesmen Perkem- bangan Anak}

\begin{tabular}{ll}
\hline Keterangan & Skor \\
\hline Rerata & 158,72 \\
Median & 160 \\
Modus & 148 \\
Nilai Maksimum & 175 \\
Nilai Minimum & 130 \\
Standar Deviasi & 14,08 \\
Varians & 198,33 \\
Jumlah Skor Data & 2857 \\
Mentah & 18 \\
Jumlah Responden & \\
\hline
\end{tabular}

Selanjutnya, rangkuman deskripsi data informasi hasil asesmen perkembangan tersebut disusun dalam tabel distribusi frekuensi (Tabel 4).

Tabel 4: Distribusi Frekuensi

\begin{tabular}{ccc}
\hline Interval & $\begin{array}{c}\text { Frekuensi } \\
\text { Absolut }\end{array}$ & $\begin{array}{c}\text { Frekuensi } \\
\text { Relatif }\end{array}$ \\
\hline $130-135$ & 1 & $5,6 \%$ \\
$136-141$ & 1 & $5,6 \%$ \\
$142-147$ & 2 & $11 \%$ \\
$148-153$ & 2 & $11 \%$ \\
$154-159$ & 3 & $16,6 \%$ \\
$160-165$ & 1 & $5,6 \%$ \\
$166-171$ & 3 & $16,6 \%$ \\
$172-177$ & 5 & $28 \%$ \\
\cline { 2 - 3 } & 18 & $100 \%$ \\
\hline
\end{tabular}

Berdasarkan tabel tersebut, jika dilihat dari nilai reratanya maka banyaknya anak yang berada di bawah nilai rata-rata sebanyak 6 anak atau 33,2\%; anak yang berada pada kelas rata-rata sebanyak 3 anak atau 16,6\%; sedangkan anak yang berada di atas kelas rata-rata sebanyak 9 anak atau 50,2\%. Jika persentase hasil asesmen perkembangan di atas dapat digambarkan dalam bentuk polygon, tampak sebagai berikut.

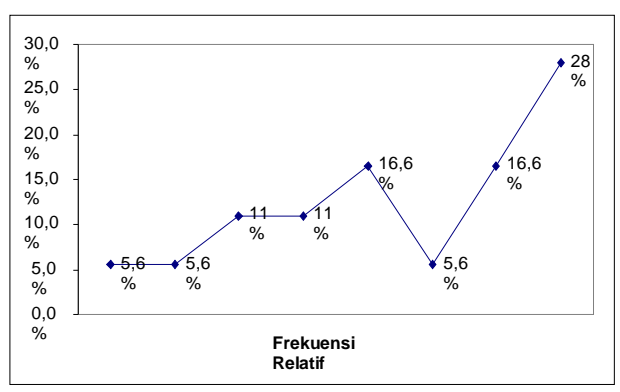

Grafik 1. Frekuensi Relatif 


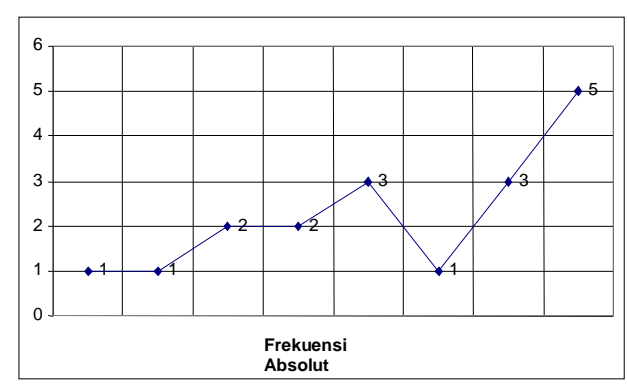

Grafik 2. Frekuensi Absolut

Berdasarkan hasil asesmen perkembangan anak, dapat disimpulkan bahwa 12 dari 18 anak memiliki katagori berkembang sesuai harapan. Itu berarti $66,8 \%$ yang memiliki katagori kemampuan berkembang sesuai harapan yang dibuktikan melalui kumpulan hasil dalam bentuk karya/produk media daur ulang dan perilaku nyata yang dapat diamati (observable) dan dapat diukur (measureable). Itu berarti penggunaan media daur ulang berbasis kecerdasan jamak dapat meningkatkan keterampilan hidup anak usia dini pada Pos PAUD di Provinsi DKI Jakarta.

\section{Perbandingan Data Nilai Rata-rata Anak Sebelum dan Sesudah Penerap- an Model}

Berikut disajikan data anak sebelum dan sesudah penerapan model (Tabel 5).

Tabel 5: Data Nilai Rata-rata Sebelum dan Sesudah Penerapan Model

\begin{tabular}{ccccccr}
\hline Kegiatan & N & Rata-rata & Standar Deviasi & Nilai t hitung & df & tabel \\
\hline Sebelum & 18 & 150,78 & 11,10 & 10,14 & 36 & 2,021 \\
Sesudah & 18 & 158,72 & 14,08 & & & \\
\hline
\end{tabular}

Berdasarkan tabel tersebut di atas, terlihat bahwa nilai rata-rata sesudah penerapan model lebih besar dan verbeda secara signifikan dengan nilai rata-rata sebelum penerapan model $(158,72$ > 150,78; dan t hitung 10,14 > ttabel 2,021).

\section{PEMBAHASAN}

Berdasarkan hasil studi pendahuluan ditemukan bahwa kompetensi guru Pos PAUD dalam menggunakan daur ulangdanmengembangkan desain pembelajaran berbasis kecerdasan jamak rata-rata masih rendah. Di lain pihak, untuk meningkatkan keterampilan hidup anak usia dini seorang guru harus dapat media daur ulang dan membuat desain pembelajaran berbasis kecerdas- an jamak yang sesuai dengan karakteristik perkembangan anak usia dini. Kenyataanini, menunjukkan kesenjangan antara kemampuan guru di Pos PAUD yang ada sekarang ini dengan kompetensi ideal yang seharusnya dikuasai untuk membelajarkan keterampilan hidup pada anak usia dini. Akibat adanya kesenjangan inilah, maka perlu dikembangkan suatu model konseptual pengembangan media daur ulang dan desain pembelajaran berbasis kecerdasan jamak untuk dapat meningkatkan keterampilan hidup anak usia dini di Pos PAUD.

Sebagai salah satu alternatif yang dapat dilakukan untuk mengatasi hal tersebut di atas dan sesuai dengan fokus dalam penelitian ini, maka telah 
dikembangkan model konseptual media daur ulang dan desain pembelajaran berbasis kecerdasan jamak untuk meningkatkan keterampilan hidup anak usia dini. Setelah dilakukan kegiatan pengembangan model program kegiatan bermain di Pos PAUD sebanyak 6 (enam) kali yang melibatkan peserta terdiri dari guru Pos PAUD 10 orang, guru taman kanak-kanak 10 orang dan mahasiswa S1 program studi pendidikan anak usia dini berjumlah 5 orang, maka hasil yang didapat berupa seperangkat kurikulum pembelajaran tertulis, yaitu: (1) pengembangan tema dan sub tema tentang rumah; (2) matriks hubungan tema dengan alokasi waktu per minggu; (3) pengembangan kegiatan puncak tema; (4) model keterpaduan tema dan indikator kecerdasan jamak; (5) satuan kegiatan mingguan dan harian.

Seperangkat model program pembelajaran keterampilan hidup dengan media daur ulang berbasis kecerdasan jamak bagi anak usia dini tersebut di atas telah dikembangkan berdasarkan landasan pengembangan program kegiatan bermain, yaitu: (1) teori perkembangan anak usia dini, aspek perkembangan, dan karakteristik perkembangan; (2) Pendekatan berpusat pada anak; (3) pendekatan konstruktivisme, (4) pendekatan kurikulum bermain kreatif bagi anak usia dini di Pos PAUD, (5) desain media daur ulang berbasis kecerdasan jamak; dan (6) sejumlah indikator kemampuan dalam keterampilan hidup pada anak usia dini.

Hasil penelitian membuktikan bahwa media daur ulang dapat digunakan untuk mengembangkan kecerdasan ja- mak, khususnya visual spasial pada pengembangan kemampuan mendeskripsikan benda secara detail, menyimpan informasi spasial dan mempergunakannya kembali dalam membuat sebuah hasil karya secara detail serta memahami hubungan spasial antar benda atau antara tubuhnya dengan benda lain. Hal ini dikarenakan terdapat beragam unsur atau materi yang dibutuhkan pada media daur ulang dalam mengembangkan beragam aspek kecerdasan visual spasial anak tersebut. Beragam unsur dan materi tersebut adalah terdapatnya garis, bentuk, warna, ukuran, jenis bahan, arah, jarak, pola yang semuanya merupakan unsurunsur yang dibutuhkan dalam mengembangkan beragam kemampuan dalam kecerdasan visual spasial anak. Selain itu, media daur ulang dapat ditemukan di mana saja, di tempat yang sangat dekat dengan anak.

\section{PENUTUP}

\section{Kesimpulan}

Berdasarkan pembahasan hasil penelitian di atas, dapat ditarik kesimpulan sebagai berikut: Pertama, kondisi awal guru di Pos PAUD masih rendah dalam mengembangkan media daur ulang berbasis kecerdasan jamak. Rendahnya kemampuan guru tersebut didasarkan pada temuan, bahwa sebagian besar guru tidak menguasai cara membuat media daur ulang berbasis kecerdasan jamak serta implementasinya dalam proses pembelajaran keterampilan hidup pada anak usia dini. Kedua, media daur ulang berbasis kecerdasan jamak telah terbukti merupakan media pembelajaran yang sesuai 
dengan konsep pembelajaran pada anak usia dini: (1) sesuai dengan tahapan, tugas, karateristik, dan kebutuhan perkembangan anak; (2) sesuai dengan indikator dari aspek kecerdasan jamak; (3) sesuai dengan pendekatan berpusat pada anak yang ditandai dengan interaksi dinamis antara pendidik dan anak atau antara anak dengan anak lainnya. Ketiga, desain pembelajaran berbasis kecerdasan jamak berorientasi pada: tujuan yang mengarah pada pengembangan keterampilan hidup pada anak; materi dikembangkan sesuai dengan karakteristik dan kebutuhan yang sesuai dengan aspek keterampilan hidup; metode yang bervariasi sesuai tujuan dan dapat melibatkan anak secara aktif, kreatif dan menyenangkan; media dan lingkungan bermain yang aman, nyaman dan menimbulkan ketertarikan bagi anak untuk bereksplorasi serta evaluasi dilakukan melalui observasi partisipatif terhadap apa yang dilihat, didengardan diperbuat anak. Keempat, berdasarkan hasil penerapan media daur ulang berbasis kecerdasan jamak yang dikembangkan cukup efektif karena 12 dari 18 anak memiliki katagori berkembang sesuai harapan pada indikator keterampilan hidup. Itu berarti penggunaan media daur ulang berbasis kecerdasan jamak berpengaruh 66,8 \% dalam meningkatkan keterampilan hidup anak usia dini pada Pos PAUD di DKI Jakarta.

\section{Implikasi dan Saran}

Penelitian ini berimplikasi pada: (1) pengembangan media, penelitian ini memberikan sumbangan berarti bagi pengembangan media daur ulang yang sesuai dengan konsep dasar pendidikan anak usia dini; (2) pengembangan desain pembelajaran berbasis kecerdasan jamak yang dapat memfasilitasi kegiatan bermain yang aktif, kreatif, aman dan menyenangkan bagi anak usia dini;(3) pengembangan kreativitas pendidik dalam mendaur-ulang beragam media bermain kreatif.

Berdasarkan kesimpulan dan implikasi di atas, maka perlu dikemukakan beberapa saran yang relevan. Pertama, bagi guru yang hendak mengembangkan media daur ulang ini perlu memiliki pemahaman komprehensif terhadap seperangkat pedoman dan tahapan kerja dari media ini, sehingga kesalahan-kesalahan yang mungkin terjadi dalam pembuatan media daur ulang di lapangan dapat dihindari. Selain itu, sangat disarankan untuk mengadakan kegiatan pengembangan media daur ulang sejenis dengan tema yang sama ataupun berbeda dengan penelitian ini. Kedua, Guru harus memiliki kreativitas dan kepekaan untuk melihat setiap hal yang dapat digunakan di lingkungan sekitar untuk dimanfaatkan dalam kegiatan belajar melalui bermain agar anak dapat mengalaminya secara langsung dan nyata (experiences and contextual learning), karena pada dasarnya laboratorium hidup tempat anak belajar yang terbesar adalah dunia dan seisinya. Ketiga, bagi penyelenggara Pos PAUD hendaknya dapat: (1) memfasilitasi dan mengadakan pembinaan bagi guru agar dapat menerapkan media daur ulang ini di kelas masing-masing; (2) melakukan kemitraan dengan orang tua secara lebih terencana, karena keefektifan dan keberhasilan pengembangan 
media daur ulang ini bukan hanya menjadi tanggungjawab pihak lembaga saja melainkan dibutuhkan juga dukungan dan partisipasi aktif dari pihak orangtua, misalnya pada saat pengumpulan bahan/imbah, orangtua memiliki andil besar terhadap kesuksesan acara tersebut. Keempat, mengingat keterbatasan penelitian ini, maka untuk mendapatkan hasil yang lebih baik perlu diadakan studi lanjutan tentang kelebihan dan kekurangan dari media daur ulang ini dan untuk melihat keefektifannya di lapangan dengan menggunakan sampel penelitian yang lebih besar agar didapat hasil yang lebih representatif dan memiliki keterdekatan dengan kenyataan di lapangan.

\section{UCAPAN TERIMA KASIH}

Selesainya penelitian ini tidak terlepas dari bantuan yang diberikan oleh beberapa pihak di antaranya Lembaga Penelitian Universitas Negeri Jakarta yang telah mendanai penelitian melalui hibah kompetensi. Tak lupa kepada editor yang telah memberikan masukan dan sumbang saran yang sangat berarti demi kesempurnaan jurnal ini, serta tim pengelola jurnal cakrawala pendidikan.

\section{DAFTAR PUSTAKA}

Amstrong, Thomas. 2002. Multiple Intelligences in the Classroom, terjemahan Yudhi Murtanto. Jakarta: Kaifa.

Borg, W.R dan M.D. Gall. 2003. Educational Research an Introduction. $7^{\text {th }}$ ed. Boston: Pearson Education, Inc.
Catron,Carol.E dan Jan Allen. 1999. Early Childhood Curriculum: A Creative Play Model, 2nd Edition. NewJersey: Merill Publ.

Departemen Pendidikan Nasional. 2008. Petunjuk Teknis Penyelenggaraan Pos PAUD. Jakarta: Direktorat PAUD, Dirjen PNFI.

Gardner, Howard. 1999. Intelligence Reframed: Multiple Intelligences for 21 th Century. USA: BasicBooks.

http://www.family-discovery.com/detail2.asp? $\mathrm{menu}=\mathrm{detail} 2 \& \mathrm{id}=6$

Maddaleno, Matilde dan Francisca Infante. 2001. Life Skills Approach to Child and Adolescent Healthy. USA: Pan American Health Organization.

Sadiman, Arief S. 2003. Media Pendidikan. Jakarta: Raja Grafindo Persada.

Stefanakis, Evangeline Harris. 2002. Multiple Intelligences and Portofolios: A Window Into The Learner's Mind. Portsmouth, NH: Heinemann.

Wirjoatmodjo, Nuning dan Fardah Assegaf. 2004. Langkah Kecil Untuk Lompatan Besar. Jakarta: UNESCO. 